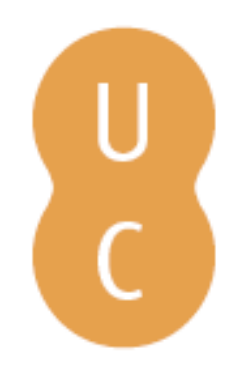

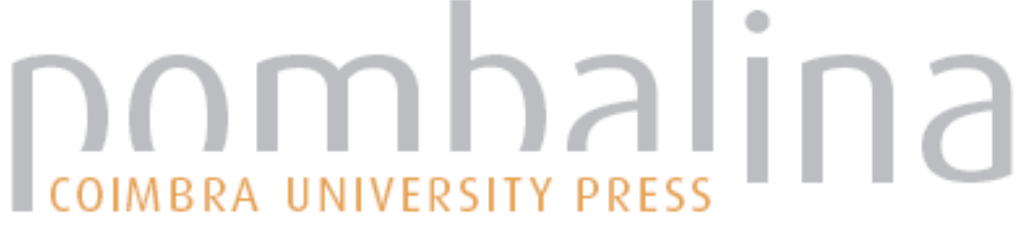

\section{Norton de Matos e a auto-defesa face à História coeva e futura}

Autor(es): $\quad$ Silva, Armando Malheiro da

Publicado por: Imprensa da Universidade de Coimbra

URL persistente:

URI:http://hdl.handle.net/10316.2/32224

DOI:

DOI:http://dx.doi.org/10.14195/978-989-26-0810-5_24

Accessed : $\quad$ 15-Feb-2021 16:01:31

A navegação consulta e descarregamento dos títulos inseridos nas Bibliotecas Digitais UC Digitalis, UC Pombalina e UC Impactum, pressupõem a aceitação plena e sem reservas dos Termos e Condições de Uso destas Bibliotecas Digitais, disponíveis em https://digitalis.uc.pt/pt-pt/termos.

Conforme exposto nos referidos Termos e Condições de Uso, o descarregamento de títulos de acesso restrito requer uma licença válida de autorização devendo o utilizador aceder ao(s) documento(s) a partir de um endereço de IP da instituição detentora da supramencionada licença.

Ao utilizador é apenas permitido o descarregamento para uso pessoal, pelo que o emprego do(s) título(s) descarregado(s) para outro fim, designadamente comercial, carece de autorização do respetivo autor ou editor da obra.

Na medida em que todas as obras da UC Digitalis se encontram protegidas pelo Código do Direito de Autor e Direitos Conexos e demais legislação aplicável, toda a cópia, parcial ou total, deste documento, nos casos em que é legalmente admitida, deverá conter ou fazer-se acompanhar por este aviso. 


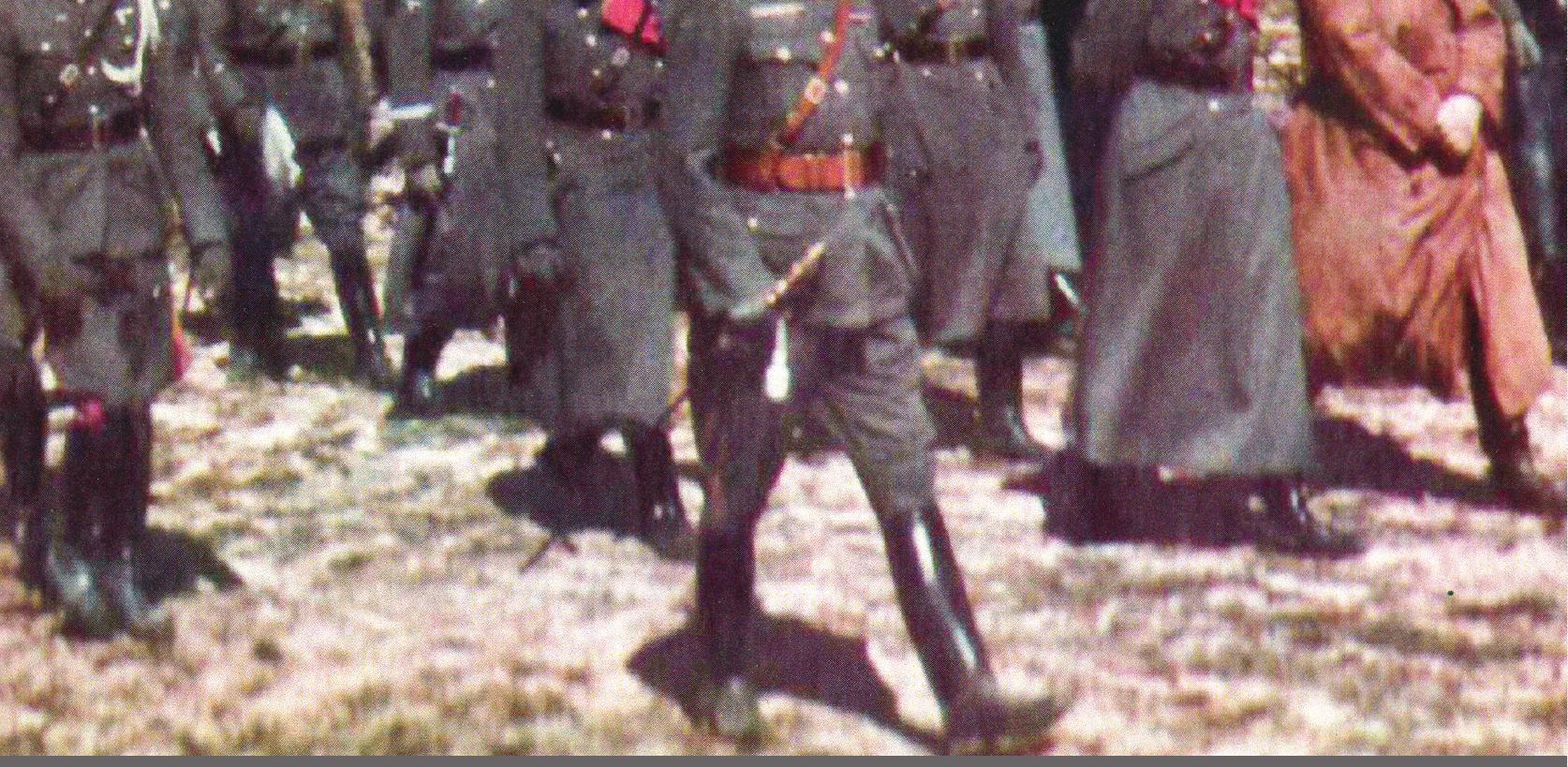

\section{Estados autoritários}

e totalitários

e suas representações

Coordenaação

Luís Reis Torgal

Heloísa Paulo

Coimbra · 2008

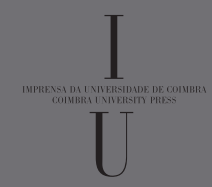




\section{Armando Malheiro da Silva}

\section{NORTON DE MATOS E A AUTO-DEFESA FACE À HISTÓRIA COEVA E FUTURA}

\section{A Memória e a História como espaço de confronto político-ideológico}

O Estado Novo português (1933-1974), sobretudo na fase fascista até ao final da II Guerra Mundial, não hesitou em configurar as bases de um pensamento único e (re)fazer a Memória para uma História representativa e legitimadora do seu Poder. O uso da Memória e da História pelo Estado Novo nada tem de original, constituindo a estratégia comum aos que disputavam e assumiam pleno controlo sobre o aparelho estatal; aos que entendiam legitimo e necessário estender a luta ideológica e politica à "gestão" do que se devia nacionalmente evocar e do que merecia ficar escrito nos manuais escolares e nos "anais" da "História pátria". E, também, do que devia ser, para sempre, esquecido.

Os republicanos e, em especial, os apoiantes de Afonso Costa, que o golpe militar de 28 de Maio de 1926 afastou do Poder, haviam já assumido essa estratégia ideo-política e ao passarem para a oposição mais ou menos frontal, reviralhista e político-eleitoral primeiramente contra os governos militares da proclamada "Ditadura Nacional" e, depois, contra os governos do Presidente do Conselho todo poderoso, o lente da Faculdade de Direito da Universidade de Coimbra, António de Oliveira Salazar, não abandonaram o espaço memorialístico e historiográfico para manter vivo o seu combate.

Um e outro lado da barricada - o Estado Novo salazarista e a Oposição republicana e democrática - exercitaram um discurso em que há simetria entre os actos de recordar e de esquecer, ou seja, em que são evocados apenas acontecimentos e situações (além de premissas ideológicas) que valorizam e enaltecem a acção das hostes a que pertence o narrador, o que implica o apagamento completo de um mínimo traço dissonante. Não faltam, aliás, exemplos de informação "manipulada" em um campo e no outro: referimo-nos sobretudo a narrativas de cariz memorialístico e auto-biográfico e de pretensos contributos para a escrita da História ${ }^{1}$. Memórias, diários e auto-biografias

\footnotetext{
${ }^{1}$ Ver SILVA, Armando Malheiro da - A Escrita vária da história da I República. Ler História, Lisboa, 38 (2000) pp. 197-254; Idem - Sidónio e sidonismo entre a história e a literatura. Revista de História das
} 
são vistos como géneros literários por uns e fontes primárias por outros (isto é, pelos historiadores), mas sem ilusões, quanto ao rigor e veracidade do seu conteúdo. Posicionamento influenciado pela crítica epistemológica ao positivismo absorvida e assumida pela historiografia do pós II Guerra Mundial. E assumida tão profundamente que não tardaria a abraçar o relativismo extremo propenso a negar à História a condição de cientificidade e a valorizar o primado da narratividade aberta ao jogo livre e contingencial das interpretaçôes provisórias e subjectivas.

Memórias e diários, a par da edição de correspondência pessoal (fonte mais genuína e muito menos "retocada"), constituem matéria-prima para o trabalho historiográfico, mas são, também, uma arena de esquecimentos e de revelações intencionais, bem como de ajustes de contas, de ressentimentos e de afirmação de princípios, valores e programas de acção caros ao protagonista/narrador. Pode ainda dizer-se que o diário funcionou como minuta ou "borrão" preparatório do trabalho memorialístico. E no caso de Norton de Matos verificou-se naturalmente a redacção diarística como prática selectiva de registo, mais ou menos coevo, dos acontecimentos e situações vividas, base informativa essencial para p acto justificativo e legitimador de (re)memorar. No respectivo Arquivo/Biblioteca ou Sistema de Informação da Família Norton de Matos (localizado na Casa da vila de Ponte do Lima) facilmente se detecta um distanciamento no tempo entre a escrita dos Diários, usados como aide-mémoire sobretudo do político republicano e maçon convidado a servir o novo regime em altos postos e com elevadas responsabilidades, e a escrita das Memórias, concretizada nos anos quarenta, período doloroso do ponto de vista familiar e particularmente intenso e grave do ponto de vista político interno e internacional.

As Memórias e Trabalhos da Minha Vida, reeditadas (com dois tomos inéditos) já neste século $^{2}$ e apenas dois anos após a primeira biografia merecedora desse qualificativo ${ }^{3}$, são a fonte principal desta comunicação e a ela voltaremos adiante, porque nela encontramos bem desenvolvida a sua estratégia discursiva de auto-defesa face à História oficial do Estado Novo e, sobretudo, face às versões de alguns ex-correligionários e dos seus adversários políticos a respeito de alguns tópicos centrais do seu pensamento/ acção colonial e político-militar.

De imediato e embora haja, acessível e credível, informação biográfica do general, não podemos deixar de sublinhar, aqui, os traços marcantes da sua personalidade $\mathrm{e}$ da sua vida.

\section{A figura singular do General José Mendes Ribeiro Norton de Matos (1867-1955)}

Ideias, Coimbra, 21 (2000), p. 307-388; e Idem - Variações ideológicas da historiografia em torno da 1. ${ }^{a}$ República Portuguesa. In: HOMEM, Amadeu Carvalho; SILVA; Armando Malheiro da; e ISAÍAS, Artur César (coord.) - Progresso e Religião: a República no Brasil e em Portugal (1889-1910). Coimbra; Uberlândia: Imprensa da Universidade de Coimbra; Editora da Universidade Federal de Uberlândia, 2007. pp. 411-428.

${ }^{2}$ MATOS, Norton de - Memórias e trabalhos da minha vida. Planificação, justificação e organização Armando Malheiro da Silva e José Pedreira Castro Norton. 3 volumes. Coimbra: Imprensa da Universidade, 2004.

${ }^{3}$ NORTON, José - Norton de Matos: biografia: fronteiras do tempo. Lisboa: Bertrand Editora, 2002. 
O general Norton de Matos permanece, sem dúvida, como uma figura proeminente da I República portuguesa (1910-1926) e do republicanismo democrático e maçónico que se prolongaria, de forma resistente, para lá do 28 de Maio de 1926. Figura singular também, porque não sendo um republicano da fase da propaganda anti-monárquica, produzida antes do 5 de Outubro de 1910, fará a sua adesão imediata ao Partido Republicano Português (PRP), alinhando depois ao lado de Afonso Costa e da sua facção, conhecida por Partido Democrático. Soube, aliás, conciliar a vertente política e uma militância maçónica intensa (chegará a Grão Mestre), com o seu espírito e perfil militares e a sua carreira de ultramarino, que, na Índia, tomou contacto com o colonialismo inglês (contacto favorecido pelas suas raízes familiares paternas na velha Albion), tornando-se, naturalmente, um especialista em matéria colonial.

Várias são as singularidades de Norton de Matos, mas importa destacar o facto de ter mantido um posicionamento muito próprio dentro das hostes afonsistas. Foi-se afastando, sem romper, da dupla Afonso Costa e Bernardino Machado (lideres do Comité de Paris após 1926), conseguiu firmar, a partir de 1930, o seu exílio em terra portuguesa (entre Lisboa e Ponte do Lima) e fez-se respeitar por Salazar, que nunca ousou "tocar-lhe" e pelos camaradas de armas, nomeadamente pelos que sustentaram o Estado Novo salazarista. Esta singularidade ajudou e não o impediu de ser, até perto da sua morte e já octogenário, o chefe da Oposição republicana em Portugal, o que, por si só, é outra curiosa singularidade que o evidencia.

Podemos, assim, sumariar e rever a sua trajectória de vida, de formação e de acção multifacetada através de um conjunto de tópicos bem vincados.

\section{Berço minhoto e liberal}

Natural de Ponte de Lima, onde nasceu a 23 de Março de 1867, tinha, pelos Norton, raízes em Dartmouth, South Devon, Inglaterra ${ }^{4}$, descendia de abastadas famílias de comerciantes, de proprietários rurais, de militares e de bacharéis fixados na Ribeira Lima.

O jovem José, quarto filho, entre nove, de Tomás Mendes Norton e D. Emília da Conceição de Matos Prego e Sousa, cresceu e formou-se num círculo familiar estável, monárquico-liberal, culto e socialmente elevado.

Após ter frequentado, durante dois anos, o Colégio do Espírito Santo, ingressou, aos treze (Março de 1880), na Escola Académica5 ${ }^{5}$, em Lisboa, cujos preparatórios concluiu

\footnotetext{
${ }^{4}$ Sobre este ramo D. Rita Mendes Norton de MATOS, irmã do general, escreveu o seguinte: Casou um inglês de nome André Norton, meu Bisavô paterno, que emigrou da Inglaterra para Portugal ao terminar o século XVIII, com uma senhora portuguesa de nome D. Ana Rosa Tavares de Rezende, da Casa de Avanca, Estarreja, de que faz parte o homem de ciência Doutor e Professor Egas Moniz único português a quem, até hoje, coube um Prémio Nobel. Muito me orgulho em ser com ele aparentado em tão directa linha, como se vê na Primeira Parte deste livro. Do casamento de André Norton com D. Ana Rosa Tavares de Rezende nasceu minha Avó paterna, D. Rita Norton (MATOS, Rita Norton de A Família Norton de Matos. Aspecto político e social duma família portuguesa. Ponte do Lima, Edição da Autora, 1953, p. 63).

${ }^{5} \mathrm{O}$ contraste entre este novo meio colegial e o anterior mereceu-lhe o seguinte comentário: "[Na Escola Académica] Falava-se livremente; liam-se jornais e livros vários; discutiamos acontecimentos públicos; e havia rapazes monárquicos e rapazes republicanos. Era já então, muito reservado em questões políticas e partidárias. A
} 
em 1884, matriculando-se de seguida no Curso de Matemática da Universidade de Coimbra. Este curso durava quatro anos e era necessário fazer - como nos explica - para poder seguir carreira militar em qualquer das armas ou serviços que então se chamavam superiores: - artilharia, engenharia ou estado maior . Da passagem pela Academia de Coimbra ficou-lhe a recordação do confronto entre "polainas" (estudantes ricos) e "briosos" (os mais "pobres e modestos", animados por "ideias niveladoras"), as diferenças de modos de pensar e de proceder entre os estudantes de Direito, de Medicina, de Matemática e de Teologia ${ }^{7}$, a indiferença com que os lentes de Direito encaravam os estudantes de Matemática a propósito da cadeira comum de Economia Política ou ainda as leituras extra-curriculares, que iriam influir bastante no seu quadro mental e ideológico: Por outro lado - conta-nos nas Memórias - já nesse tempo [1884-1888] principiaram a circular pela Academia folhetos socialistas e num deles apresentava-se em resumo, "O Capital" de Karl Marx. Adquiri-os e a sua leitura levou-me a comprar as obras de Proudhon. Direi, a propósito, que do que li no meu tempo de estudante e da Escola do Exército nada teve tanta influência sobre mim como os livros de Proudhon ${ }^{8}$.

Marcante seria, também, o período que se seguiu à conclusão do curso de oficial do Estado Maior, em 1890 , e decorreu até $1898^{9}$, na medida em que o projectou para fora do rectângulo nacional e para muito longe - as "possessóes" restantes da quinhentista Índia portuguesa.

\section{Militar agrimensor ultramarino}

Na carreira profissional de Norton de Matos foi decisiva, de facto, a partida para a Índia ${ }^{10}$, nomeado, a 4 de Agosto de 1898, para director da Repartição de Agrimensura do Estado da Índia, criada nesse mesmo dia por portaria provincial no 569 . Começou, então, um tirocínio de dez anos no domínio do fomento colonial, preenchido pela execução da triangulação secundária do território e do cadastro predial, rural e urbano, tarefas acumuladas com várias missões de estudo técnico-administrativo à Índia inglesa, com outros serviços e muitas comissões, como a de administrador das Matas, director das Obras Públicas, membro do Conselho do Governo, etc. O testemunho da irmã,

política de facto nunca me disse muito e os partidos só mais tarde, após a proclamação da República, principiei a ver bem o que eram, os seus inconvenientes e as suas vantagens, a sua absoluta necessidade para a moralização da vida pública" (MATOS, Norton de - Memórias e trabalhos da minha vida, ob. cit., vol. 1, tomo 1, p. 69).

${ }^{6}$ Idem, ob. cit., p. 87.

7 Ibidem, p. 90.

${ }^{8}$ Ibidem, p. 91.

${ }^{9}$ Reconhece-o nas suas Memórias, mas de um modo evasivo e genérico: Bem ou mal, os anos que decorreram de 1890 a 1898 marcaram na minha vida profundamente. Tenho de fazer um esfôrço para me recordar do que nêles se passou de essencial para a formação do meu espírito, para destacar dessa nublosa época as pedras brancas e negras que foram ficando ao longo do meu caminho. Será difícil... Hesitações, absoluta dificuldade de adaptação a um meio inteiramente contrário ao meu intimo sentir, algumas loucuras de mocidade, desfalecimentos de vontade, mas ao mesmo tempo um grande sentimento de dignidade, de lealdade, de ausência completa de inveja ou de maldade, que nunca permitiram durante a minha longa vida a prática de qualquer baixeza que leve fôsse (Ibidem, vol. 1, tomo 1, p. 96-97). Ver NORTON, José - Norton de Matos, ob. cit., pp. 73-107.

${ }^{10}$ Ver NORTON, José - ob. cit., pp. 107-164. 
D. Rita ${ }^{11}$, leva-nos a admitir que ao cabo de tão longa e intensa permanência nessas longínquas paragens do Império, onde se pressentia ainda a "concepção gigantesca e perfeita de Albuquerque", Norton de Matos descobrira uma paixão e um desígnio - o estudo e a prática da colonização no Mundo moderno.

Regressado à Metrópole em 1908, o capitão Norton de Matos seguiu, pouco depois, para Macau na qualidade de secretário da missão diplomática presidida pelo General Joaquim Machado e destinada a tratar com a China os limites daquele território ${ }^{12}$.

\section{Servir a República e a Maçonaria, ir à Guerra e gizar a Nação Una a partir de Angola}

Em meados de 1910, estava de volta a Portugal e os dois anos seguintes seriam vividos na "caserna": começou por fazer serviço no corpo do Estado Maior, sendo depois colocado na Divisão Militar sedeada em Viseu, mas por muito pouco tempo... Em serviço de confiança do General Correia Barreto, então Ministro da Guerra, passou, já como major, a exercer o lugar de Chefe do Estado Maior em Coimbra. Data, também, deste período a sua nomeação, por concurso, para professor de Geodesia e Topografia do Instituto Superior Técnico de Lisboa, donde será compulsivamente afastado, a 16 de Maio de 1935, por motivos políticos.

Em Abril de 1912 era nomeado Governador-Geral de Angola e a 17 do mês seguinte era iniciado maçon na Loja "Pátria e Liberdade", no 332, de Lisboa (rito escocês), com o nome simbólico de Danton, tendo-se comprometido, no acto da iniciação, a abolir efectivamente a escravatura. Parte para Luanda no navio "Beira" a 1 de Junho e irá permanecer, aí, até 8 de Março de 1915, dia do regresso a Lisboa, após ter pedido a demissão ao Ministro das Colónias do Governo Pimenta de Castro.

Esses dois anos e cerca de nove meses em Angola ficariam marcados por um vasto conjunto de medidas e de iniciativas típicas do modelo fomentista, assimilacionista e descentralizador com que Norton de Matos defendeu a colonização. Foi um período de intensa actividade e de momentos graves, especialmente a invasão alemã do sul de Angola, o combate de Naulila a 18 de Dezembro de 1914 e a retirada das forças portuguesas comandadas por Alves Roçadas.

Estes factos causaram-lhe uma forte impressão. Juntou, por isso, muitos documentos e deixou muitas páginas escritas, em artigos de jornal, no Diário (inédito) e nas Memórias (volumes publicados e inéditos), mas o que mais interessa ressaltar são os seus sentimentos anglófilos e anti-germânicos. Assim se expressa, por exemplo, neste pedaço de prosa memorialista: Tinha, por todas estas razôes, de reconhecer que o aparecimento da Alemanha no continente africano nos estava criando uma situação cheia de mal entendidos

${ }^{11}$ Merece ser transcrito o seguinte comentário de D. Rita Norton de Matos: Nessa dezena de anos passados na India foi grande a influência que teve na "formação" de meu irmão o passado de grandeza que nessas paragens deixamos e muito o impressionou, como revela em cartas que nos escreveu, a concepção gigantesca e perfeita de Albuquerque, consistindo na transformação do pequeno Portugal num grande império, graças à sua expansão para a África e para o Oriente, livrando-o assim de constantes ameaças. Começou então a germinar no seu espírito a ideia da Nação Una, da Unidade Nacional, resultante da fusão intima e completa, sob o ponto de vista nacional, social, territorial e económico, de todas as regioes portuguesas pelo mundo espalhadas (Idem - A Família Norton de Matos, ob. cit., p. 109).

12 Ver NORTON, José - Norton de Matos, ob. cit., pp. 165-172. 
entre nós e a Inglaterra, e de grandes perigos. O meu coração de homem, de português e de aliado sentia-se profundamente ferido com o que se passara em 1898, que imperfeitamente conhecia então, e com o que, tudo mo dizia, se estava passando em 1912. Aquele fermento germânico, que tanto perturbava o povo português em horas amargas, estava a alterar $o$ carácter britânico, limpido e leal, que tanto me habituara a apreciar ${ }^{13}$.

Interrompidas, pois, a seu pedido, as funções de Governador Geral, e regressado, entretanto, a Lisboa, o major Norton de Matos embrenha-se na luta partidária, participando, ao lado de outros democráticos ou afonsistas - Álvaro de Castro, Sá Cardoso, António Maria da Silva e Freitas Ribeiro - numa conspiração triunfante contra a ditadura de Pimenta de Castro (o célebre 14 de Maio de 1915). A conjuntura era dramática e complexa. Uma guerra de proporções inusitadas, com várias frentes (europeia, africana, palestiniana...) trucidava, implacável, milhares de pessoas.

Os dois efémeros Governos de José de Castro, que se sucedem de 17 de Maio de 1915 até à formação do segundo Governo de Afonso Costa, em 29 de Novembro desse mesmo ano, contam já com a presença do deputado democrático Norton de Matos, primeiro como Ministro das Colónias e depois, nas pastas da Guerra e dos Negócios Estrangeiros. No segundo Governo Afonso Costa, no da efémera "União Sagrada” (à qual não aderiram os unionistas) e no terceiro Governo afonsista, Norton de Matos manteve-se nessa decisiva pasta da Guerra.

Durante tão difícil e instável fase governativa, o coronel Norton de Matos viu o seu prestígio crescer de forma exponencial quer dentro do Partido Democrático (chegou a membro efectivo do Directório), quer no seio da Maçonaria (transitou da sua Loja de origem para a Loja "Acácia” de rito francês e integrada no Grande Oriente Lusitano Unido), e conseguiu organizar, com poucos meios e manifesta falta de tempo, o Corpo Expedicionário Português - motivo tanto de orgulho próprio e dos seus correligionários, como de crítica cerrada por parte dos anti-guerristas ${ }^{14}$. Não admira, por isso, que a ira dos descontentes o vitimasse, a par, obviamente, de Afonso Costa e de Bernardino Machado, na sequência do golpe sidonista de 5 a 8 de Dezembro de 1917, ao qual não conseguiu, enquanto Presidente interino do Ministério e Ministro da Guerra, opor uma eficaz resistência. A sua casa na Avenida Miguel Bombarda, no 109, foi assaltada e teve de se refugiar no navio de guerra inglês Woodnut. Considerado desertor pelo $1^{\circ}$ Governo do major doutor Sidónio Pais foi demitido do Exército.

Enquanto durou a experiência sidonista, ou seja, até ao assassinato de Sidónio a 14 de Dezembro de 1918, Norton de Matos permaneceu exilado em Londres, de onde seguiu o evoluir dos acontecimentos políticos em Portugal e os dramáticos episódios da guerra, sobretudo, na frente europeia.

Reintegrado no Exército com o posto de coronel até ser promovido, em 4 de Setembro de 1919, a general, agraciado com a grã-cruz da Torre e Espada, na vigência do Governo José Relvas (formado a 27 de Janeiro de 1919, após o malogro das tentativas restauracionistas da Monarquia do Norte e de Monsanto), foi nomeado delegado à

\footnotetext{
${ }^{13}$ MATOS, Norton de - Memórias..., ob. cit., vol. 2, tomo 3, p. 35.

${ }^{14}$ Ver MEDINA, João (apresentação) - Portugal na Grande Guerra. “Guerristas" e "Antiguerristas”. Estudos $e$ documentos. Lisboa, Centro de História da Universidade de Lisboa/Instituto Nacional de Investigação Científica, 1986.
} 
Conferência de Paz ${ }^{15}$ e manteve-se nessas funções até Julho desse ano, mês em que regressa a Portugal e aqui se fixa, mas por pouco tempo... Em Abril de 1920 recebe o convite do Ministro das Colónias, Utra Machado, para ocupar o cargo, recém-criado, de Alto Comissário em Angola.

Investido de amplos poderes, dado que a Lei no 1005 de 7 de Agosto de 1920 concedia às colónias uma acentuada autonomia e as Leis no 1130 e 1131 (de 26 de Março de 1921) autorizavam os Altos Comissários a fazerem empréstimos e a relacionarem-se directamente com o Banco Nacional Ultramarino, apostou, de novo, num programa colonial "recortado" na acção e no pensamento do Marquês de Sá da Bandeira ${ }^{16}$ e de Paiva Couceiro, e projectado num vasto rol de medidas. Mas a ousada aplicação de um tal programa acabou por chocar com os interesses de poderosas entidades como eram a Companhia dos Diamantes de Angola e o Banco Nacional Ultramarino. O seu "estilo" de governação, o recurso a empréstimos e o alegado descontrolo das despesas públicas deram pretexto a campanhas hostis na Metrópole, como a encabeçada por Cunha Leal e condensada no seu verrinoso livro Calígula em Angola ou como a que germinou no seio do Congresso dos Deputado e a par de uma relação, por vezes, tensa e conflituosa com a tutela (é o caso do conflito com o Ministro das Colónias Rodrigues Gaspar). Em Setembro de 1924 parte para Lisboa e em Fevereiro de 1925 enfrenta e participa no debate parlamentar sobre a sua política. Sente-se "traído", defende-se com o livro $A$ Provincia de Angola ${ }^{17}$ e aguenta a pressão das "críticas e calúnias" até ao mês de Junho desse ano. Pede e é-lhe concedida a demissão de Alto Comissário.

Não tardou, porém, a ser nomeado Embaixador de Portugal em Londres ${ }^{18}$, para onde partiu no mês de Agosto de 1925 e onde, como se sabe, estivera exilado durante a "situação" sidonista. E será nesse posto diplomático que a Ditadura Militar, saída do 28 de Maio de 1926, o foi encontrar e logo que pôde - a 21 de Junho - exonerou-o.

\section{Contra o "reviralho", a "ditadura das armas" e a "tirania de Salazar"}

Com cerca de 59 anos de idade, o general Norton de Matos entrava numa nova e difícil fase da sua vida, marcada pelo confronto político com as autoridades da Ditadura e depois com o Estado Novo de Salazar. Em consequência da sua participação

\footnotetext{
${ }^{15}$ Sobre os trabalhos da Conferência e o contributo de Norton de Matos, no âmbito da delegação portuguesa, ver FERREIRA, José Medeiros - Portugal na Conferência de Paz. Paris, 1919. Lisboa, Quetzal Editores, 1992, p. 72-77; e ainda NORTON, José - Norton de Matos, ob. cit., pp. 266-272.

${ }^{16} \mathrm{Da}$ correspondência particular entre o general Norton de Matos e o coronel Henrique Pires Monteiro destacámos uma carta deste último, de 18 de Janeiro de 1945, onde se lê a dado passo: De Gastão Sousa Dias recebi uma carta datada de 29 de Setembro, de Sá da Bandeira, em que me diz, em resposta: "Li já, como não podia deixar de ser, os dois volumes das "Memórias" do Sr. General Norton de Mattos, que aqui em Angola têm sido muito apreciadas. São livros de uma grande elevação patriotica e moral, que focam todos os problemas angolanos, sobretudo o do indigena com visão verdadeiramente genial. Depois de Sá da Bandeira ninguém mais falou assim". E Sousa Dias continua: "Dias antes tinha eu acabado de ler "O trabalho rural africano" dessa grande figura do Constitucionalismo. São filhos da mesma alma...” (Sistema de Informação Família Norton de Matos [S.I.F.M.N.]- Correspondência com o Pires Monteiro. Papéis para classificar. Carta de Pires Monteiro de 18-1-1945, fls. 1v.-2. Pasta "Memórias").

${ }^{17}$ Ver MATOS, Norton de - A Provincia de Angola. Porto, Edição de Maranus, 1926, p. 390.

${ }^{18}$ Ver NORTON, José - Norton de Matos, ob. cit., pp. 282-312.
} 
na revolta falhada de 3 a 9 de Fevereiro de 1929 foi preso e enviado para a ilha de S. Miguel (Açores), fixando residência na cidade de Ponta Delgada, onde se lhe juntou a mulher, D. Ester Newton Pereira de Matos, companheira de jornadas desde a já remota e saudosa partida para a Índia...

Durante a permanência em Ponta Delgada verá o seu nome proposto pela Loja "Acácia" (a 6 de Dezembro de 1928) para Grão-Mestre adjunto da Maçonaria Portuguesa. A 7 de Dezembro morre o Grão Mestre Sebastiāo de Magalhães Lima e o sucessor eleito, António José de Almeida, morrerá, também, uns meses depois - a 31 de Outubro de 1929. Já regressado a Portugal, Norton de Matos acaba por ser eleito Grão Mestre, a 31 de Dezembro, para os anos de 1930 e 1931, mas só tomará posse a 30 de Abril de 1930. Desenvolverá, então, intensa actividade, participando em encontros maçónicos de carácter internacional. Reeleito Grão-Mestre prosseguirá, nos anos seguintes, os seus esforços em prol dos ideais maçónicos. No início de 1935, protestou publicamente contra o projecto de lei da Assembleia Nacional que proibia as associações secretas ${ }^{19}$ e que seria, não obstante a controvérsia gerada e os protestos de pessoas de quadrantes diversos e de intelectuais como Fernando Pessoa, aprovada e publicada no Diário do Governo de 21 de Maio desse ano.

A par de um tão intenso empenhamento na vida interna da Maçonaria Portuguesa, não deixou de se envolver politicamente na luta contra a Ditadura e o Estado Novo, presidindo à Aliança Republicano-Socialista (1931) e sendo vítima da repressão estatal. Durante a revolta da Madeira, iniciada em 4 de Abril de $1931^{20}$ e logo propagada aos Açores, foi detido no Hospital Militar da Estrela, desde 10 de Abril até meados de Maio. Não voltará a ser preso, mas a sua acção ficará sob vigilância e a sua carreira profissional afectada: em 1935 é obrigado a abandonar o I.S.T., passa à situação de reforma no Exército e liga-se à actividade empresarial ${ }^{21}$.

Alternando a residência entre os arredores de Lisboa e Ponte de Lima, o general Norton de Matos dedicou os seus últimos dez anos de vida ao estudo de matérias técnico-científicas, nomeadamente a Fotogrametria, e político-coloniais, preparando para a História um conjunto de trabalhos, em que avultam as referidas Memórias e Trabalhos da Minha Vida, África Nossa e $A$ Nação Una ${ }^{22}$, além de um considerável acervo de artigos para a imprensa (colabora, desde 29 de Maio de 1931, n’O Primeiro

${ }^{19}$ Data de 31 de Janeiro de 1935 a importante carta de Norton de Matos, Grão Mestre da Maçonaria, ao Presidente da Assembleia Nacional, José Alberto Reis. É um documento de 4 fls., dactiloscrito, policopiado e estruturado em XII pontos argumentativos contra à lógica repressiva do referido projecto-lei. O exemplar que conhecemos possui umas notas autógrafas de Norton de Matos nas margens da $1 .^{\text {a }} \mathrm{fl}$, a saber: Para a Rita e o Raul lerem e guardarem. // José // Lisboa, 31 de Janeiro de 1935 (...) Para a Emilinha, sobrinha querida ler e guardar como recordação do meu proceder e do meu espirito. // Ponte do Lima, 15 de Setembro de 1946 (S.I.F.N.M. - dossier Maçonaria).

${ }^{20}$ Para a história desta revolta política veja-se, por exemplo, VARÃO, António Fernandes - Infantaria 13 no movimento político da Madeira de 4 de Abril de 1931. (Palavras dum vencido). Faro de Vigo, 1932. Citámos o exemplar existente em Ponte de Lima e que tem a seguinte dedicatória: Ao Ex.mo Snr. General Norton de Matos, ilustre republicano e estadista, homenagem do subordinado e amigo // António Fernandes Varão // Cabo Verde, S. Vicente // 16 de Setembro de 1933 (S.I.F.N.M.).

${ }^{21}$ Ver NORTON, José - Norton de Matos, ob. cit., pp. 353-354.

${ }^{22}$ MATOS, Norton de - África nossa. O que queremos e o que não queremos nas nossas terras de África. Porto, Edições Maranus, 1953; e Idem - A Nação una. Organização política e administrativa dos territórios do ultramar português. Com um prefácio do Prof. Egas Moniz. Lisboa, Paulino Ferreira, 1953. 
de Janeiro, estendendo-se ainda ao Diário de Lisboa, República e Província de Angola) e de "séries" temáticas, tais como o Diário ou Memórias e Diário, onde continuou a registar a sua impressão sobre os acontecimentos nacionais e internacionais, e que constitui - basta ler o sub-titulo - o núcleo básico da presente comunicação.

Apesar do natural desgaste da idade, do "recolhimento literário" que impusera a si mesmo e dos desgostos de ordem pessoal que o abalaram imenso (a morte da sua única neta Ester Cândida a 20 de Dezembro de 1940 e a da esposa a 7 de Abril de 1941), o oposicionista Norton de Matos não se esquivou aos apelos para um regresso à política activa, assumindo em 1943 a presidência do MUNAF e da Junta Consultiva do MUD e aceitando, por fim, candidatar-se à Presidência da República ${ }^{23}$, numa conjuntura particularmente difícil e delicada para o Estado Novo, dada a vitória dos Aliados e das ideias democráticas e socialistas sobre o fascismo e o nazismo. Quase octogenário, tornou-se o chefe incontestado de uma "oposição indomada e indomável", congregação heteróclita de facçóes, que o seu perfil de moderado e o seu constante anti-salazarismo permitiu unir num objectivo comum: "o derrube da ditadura pelas forças democráticas" ${ }^{24}$. Mas a autarcia salazarista estava empenhada em defender-se dos ataques dessas forças por todos os meios. E a 12 de Fevereiro de 1949, o velho general, alegando falta de condições para poder levar até ao fim, de forma pacífica, a sua candidatura, anunciava a inevitável desistência.

Saía, assim e de novo, vencido de um confronto desigual com Oliveira Salazar e com o candidato presidencial do regime - o Marechal Carmona -, mas continuava disponível para novos combates. Aos 86 anos de idade, mais precisamente em Agosto de 1953, profere uma conferência, em Aveiro, por ocasião da campanha eleitoral para deputados, e exprime aí, taxativamente, o seu ideário político e a sua mentalidade cívica: (...) Respondi que diligenciaria levar o Executivo a fazer-lhes [aos comunistas] a maior das oposiçôes: - na Metrópole sem quaisquer violências, mas pela maior propaganda e a melhor organizada possivel, ainda que para isso tivesse o Estado de gastar avultada quantia: no Ultramar por meio de uma lei que não permitisse que qualquer comunista se conservasse naquela parte dos territórios portugueses e que fossem mandados todos eles regressar à Metrópole para ouvirem a propaganda que contra eles estavam fazendo os brancos metropolitanos e para publicamente dizerem de sua razão. De modo algum, se pode consentir a propaganda comunista feita a pretos de civilização primitiva, que em consequência dela serão levados a uma única conclusão - a da necessidade de eliminar todos os brancos. (...) O "meu segundo apelo" consiste em apontar a absoluta necessidade de se entrar francamente e rapidamente num regime de liberdade que politicamente coloque Portugal ao nivel das grandes naçôes como sejam a França, a Inglaterra e os Estados-Unidos da América ${ }^{25}$.

${ }^{23}$ Ver SILVA, Armando Malheiro da - Para a história da oposição ao Estado Novo: a candidatura à Presidência da República do general Norton de Matos e o boletim Eleiçōes Livres no distrito (1949).Bracara Augusta, Braga, 50, 104-105, fasc. 117-118 (2001-02) p. 327-405; e Idem - O Major e o General: o apoio de Miguel Ferreira e de seus correligionários, no distrito de Braga, à candidatura presidencial de Norton de Matos (1948-49), In: Actas das Terceiras Jornadas de História Local: Fafe Século XX: alguns aspectos. Fafe: Câmara Municipal, 2002, pp. 455-551.

${ }^{24}$ ROSAS, Fernando et al. (org.) - Uma oposição indomada e indomável. Campanha eleitoral do general Norton de Matos 1948/49. Catálogo. Lisboa, Biblioteca Museu República e Resistência/Câmara Municipal de Lisboa, 1994. Veja-se, sobretudo, "Fontes e bibliografia de apoio: obras consultadas", pp. 54-56.

${ }^{25}$ MATOS, Norton de - Conferência. Aveiro, Edição dos Candidatos Democratas por Aveiro, 1953, pp. $14-15$ 
Doente e atormentado, fixou-se na sua casa de Ponte de Lima, em "convívio" constante e balsâmico com livros, jornais, revistas e velhos papéis. Confiado num "juízo" favorável da História, aguardou a morte. E ela chegou num dia de Inverno - 2 de Janeiro de $1955^{26}$.

\section{3. "Memorar" 27 contra a difamação e contra um "mau juízo" da História}

A sinopse biográfica evocada permitem enquadrar e, em especial, pôr em relevo quatro tópicos controversos do comportamento político e ideológico de Norton de Matos quando exerceu certas funções públicas:

(A) como Governador-Geral de Angola na década de dez e Alto-Comissário em Angola na primeira metade da década de vinte a sua acção (reflexo vivo do seu ideário maçónico e democrático) distinguiu-se e impôs-se, deixando marcas indeléveis, mas também uma contestação feroz que o atingiria duramente;

(B) como Ministro da Guerra entre 1915 e 1917 foi o responsável pelo, então denominado, Milagre de Tancos, ou seja, a preparação do Corpo Expedicionário Português (C.E.P.), contingente de tropas que num prazo relâmpago de meia dúzia de meses embarcou para a Flandres a fim de combater, ao lado dos Aliados, contra os alemães;

(C) o golpe militar de Sidónio Pais de 5 a 8 de Dezembro de 1917 lançou-o na sua primeira dura experiência de exílio político em Inglaterra e possibilitou que os anti-guerristas como o general Amílcar Mota ensaiassem no Congresso dos Deputados um "processo de condenação" política e pública desse Milagre, visto por eles como Pesadelo ${ }^{28}$; e

(D) na sequência da sua tão vigorosa, quão difícil e atribulada candidatura à Presidência da República, tendo desistido quase à boca das urnas contra a sua vontade, guardou até morrer uma profunda mágoa e desconfiança critica contra os comunistas.

Enunciados os tópicos, chegou o momento de os observarmos com atenção.

Tópico A:

É, sem dúvida, o mais central no seu curriculum vitae e em prol do qual investiu tanta energia, tantos cuidados e colheu bastante amargura. O seu biógrafo deteve-se no Capítulo 9 a acompanhá-lo na sua missão de Alto-Comissário em Angola, que significou um regresso ao local do seu visionarismo de fomentista colonial e de mentor

${ }^{26}$ Para a elaboração deste apontamento biográfico recorremos à imprescindível Cronologia in: GRÉMIO LUSITANO - Norton de Matos (1867-1955) no $25^{\circ}$ aniversário da sua morte. Catálogo da exposição na Biblioteca Nacional de Lisboa organizada pelo... e com introdução de A. H. de Oliveira Marques. Lisboa, Biblioteca Nacional, Junho de 1980 (policop.).

${ }^{27}$ São do punho do general estas palavras: "Memorar" é, sem dúvida, a função deste volume e dos mais que se lhe vão seguir... "Recordar" é o trabalho que a mim próprio impus para não meditar demasiadamente... (MATOS, Norton de - Memórias e trabalhos..., ob. cit., vol. 1, tomo 1, p. 118).

${ }^{28}$ Ver SILVA, Armando Malheiro - Sidónio e Sidonismo: vol. 1 História de uma vida; vol. 2 - História de um caso político. Coimbra: Imprensa da Universidade, 2006. 
de um vasto Portugal uno e diverso, capaz de reeditar a mitológica epopeia, cantada por Luís de Camões em Os Lusíadas, de Nação descobridora e civilizadora pelas sete partidas do Mundo. Foi um regresso estimulante e uma aventura espinhosa, no fim da qual, em finais de 1923 e meados de 1924, havia, como sintetizou José Norton, Muita gente a bater num homem só ${ }^{29}$ :

O Banco Nacional Ultramarino, pela mão do seu governador João Ulrich, publica uma carta aberta à Associação de Luanda, em resposta aos ataques desta. O objectivo do banco, segundo Quirino de Jesus, técnico que o governo encarregara de estudar a situação monetária e creditícia de Angola, era "atirar para cima do alto-comissário todas as responsabilidades da crise. Tentava mesmo voltar, se fosse possível, contra o primeiro magistrado de Angola o comercio da província”. Cinicamente o banco declarava-se pronto a salvar o comercio se o governo regional prescindisse das transferências mensais que contratara e devolvesse uma parte dos empréstimos concedidos, pondo então esses meios ao serviço das transacçôes mercantis!

Foi com este problema sem resolução, com a economia de Angola estrangulada, que se agendou a interpelação ao ministro das Colónias sobre o resultado da acção dos altos-comissários (para Moçambique também tinha sido nomeado um), que se viria a prolongar por vários dias.

Cunha Leal funcionou como o testa-de-ferro de todos aqueles que em Angola se sentiam descontentes com Norton de Matos, mas sobretudo os que lhe disputavam o poder. Não foi só Venâncio Guimarães. Muitos outros lhe foram fornecendo a lenha com que haviam decidido queimar Norton de Matos. Continuava activo em Angola o grupo de Simões Raposo que já em 1912 se lhe opusera, a que outros nomes se vieram juntar, não sendo dos menos activos, Galileu Correia, cambista, membro do Conselho Legislativo e com peso na forte Associação Comercial de Luanda.

Fruto de despeitos, invejas ou verdadeiras situações de injustiça, chegaram-lhe à mão elementos pormenorizados de um sem-número de questões isoladas, relacionadas com a administração de Angola.

Por outro lado, com a ajuda de pessoal do Ministério das Colónias, que como perdigueiros andavam no rasto de Norton, trouxe a público muitos documentos reservados e confidenciais, que traduziam divergências de opinião e criticas do funcionalismo em relação a actuaçôes do alto-comissário.

O próprio governo de Angola, através dos muitos que na cara de Norton de Matos se acobardavam, mas que pela calada o traíam, promoveu caudalosa fuga de informações.

Mesmo sem ter conhecimento directo de muitos dos casos, Cunha Leal conseguiu pinta-los com as cores fortes da sua veia de tribuno, arrasando por completo a acção de Norton de Matos ${ }^{30}$

A demolidora carga de Cunhal Leal sobre a actuação governativa de Norton de Matos em Angola, esmiuçada, como se vê, pelo seu credível biógrafo e de que extractamos apenas uma parcela significativa, ajuda a compreender como o abandono de funções

\footnotetext{
${ }^{29}$ NORTON, José - Norton de Matos, ob. cit., p. 293.

${ }^{30}$ NORTON, José - Norton de Matos, ob. cit., pp. 293-294.
} 
foi traumático para o general e foi-o, sobretudo, por ser ferido por farpas saídas das hostes republicanas. E contra elas se procurou defender redigindo em 1925, quando já desempenhava funçôes diplomáticas como Embaixador de Portugal em Londres, e publicando em 1926, o livro A Provincia de Angola, que constituiu um primeiro e urgente acto de auto-defesa. Seguiu-se-lhe até quase ao fim da vida, até ao seu $A$ Nação Una, submetido, sem sucesso e apesar do voto favorável de seu parente Professor Egas Moniz, a concurso do Prémio Abílio Lopes do Rego sobre administração colonial da Academia das Ciências de Lisboa, em 1952, uma profusão imensa de páginas escritas sobre questôes coloniais e, forçosamente, sobre a justeza das medidas que tomou quando investido do dificílimo dever de passar da teoria à prática num vasto território ultramarino onde quase tudo estava por fazer. Onde urgia, na sua visão fomentista e civilizadora, impor a presença institucional e administrativa da República por todo o lado através de uma concepção descentralizadora face à Metrópole, ensinar a língua pátria, assimilar as populaçôes indígenas, abolir formas directas e indirectas de escravatura (o regime do indigenato era, por isso, para ele um alvo a abater) e atrair abundantes somas de capital à província mediante a celebração de empréstimo e da criação de oportunidades de negócio nos sectores primário e secundário ${ }^{31}$.

As questões coloniais e a defesa do programa fomentista em Angola avultam, de facto, como o tópico dominante na escrita de Norton de Matos para a posteridade. Desde 1931, na colaboração periodística que manteve com o Primeiro de Janeiro e se estendeu a outros jornais, nomeadamente, a Província de Angola, e em apontamentos manuscritos, que foram engrossando dossiês rotulados de para as Memórias, teceu paciente e persistentemente um corpus de doutrina teórico-prática tendente a modernizar e a perpetuar, utopicamente, o que Gervase Clarence-Smith designou de terceiro império português ${ }^{32}$ ou, simplesmente, império africano na expressão usada por Valentim Alexandre ${ }^{33}$. Utopicamente, porque a concepção colonial de Norton de Matos, fruto de uma época e de uma mentalidade, baseava-se na idealização do papel de Portugal como potência civilizadora com vocação e destino especiais, ditados pelo legado da ínclita geração (sécs. XIV-XV) e pelo caso modelar do Brasil, no modo de relacionar-se com diferentes povos, arrancando-os alegadamente das trevas e da barbárie. A utopia do general ficou consubstanciada nas suas Memórias e trabalhos da minha vida ${ }^{34}$ (nos quatro volumes de 1943-1945 e nos dois que ficaram inéditos até

31 Ver SILVA, Armando Malheiro da; GARCIA, José Luís - Norton de Matos e a oposição à política colonial de Salazar. Revista de História das Ideias. Coimbra, 17 (1995), p. 349-404; e SILVA, Armando Malheiro da - General Norton de Matos (1867-1955): aspectos maiores de um perfil histórico-biográfico: o militar, o colonialista e o democrata. Africana Studia. Revista Internacional de Estudos Africanos. Porto, 6 (2003), pp. 176-192.

32 Ver CLARENCE-SMITH, Gervase - O Terceiro império português (1825-1975). Lisboa: Editorial Teorema, 1985.

${ }^{33}$ Ver ALEXANDRE, Valentim - Origens do colonialismo português moderno (1822-1891). In: Portugal no século XIX: antologia de textos históricos. Lisboa: Sá da Costa Editora, 1979.

${ }^{34}$ Parece-nos oportuno destacar a explicação editorial dada no estudo inserto no primeiro volume das Memórias (re)editadas (em três volumes, contendo dois tomos cada um): Antes porém de juntar num mesmo todo as duas partes, a já conhecida e a inédita, parece útil que nos detenhamos sobre algumas questöes que, sendo de interesse biográfico, nos ajudarão a melhor compreender o trabalho e o seu autor. Tentemos perceber, em primeiro lugar, o motivo ou motivos que terão levado à interrupção apos a edição do volume IV em 1945. 
2004) e teve o seu texto culminante em A Nação Una, em cujo capítulo de abertura Desígnio é dito de forma lapidar:

I - O fim deste estudo, o seu propósito único, é clamar perante o povo português na sua totalidade, seja qual for a terra onde habite, a sua raça, a sua cor, que crie a Nação Una, que a erga forte e esplendorosa.

II - A Unidade da Nação não existe ainda, apesar de a termos visionado há cinco séculos. Apenas a sentimos, mais do que a vemos, na região a que se chama "Metrópole"; à sua não existência se deve o início de pretensões separatistas em cada uma das partes da Nação, que, a desenvolverem-se, serão a causa de isolamentos, de afastamento ao invés de ligação; na Metrópole só poderá manifestar-se em forte verdade a unidade nacional, quando essa unidade se expandir intensamente para as outras partes da Nação e quando delas voltar de ricochete ao seu ponto de partida. Tudo continuará a depender da força de atracção do velho Portugal; se esta força cessar, a Pátria desaparecerá e as diversas partes da Nação ou se tornarão independentes ou irão alargar outras nações ${ }^{35}$

Por este extracto capta-se a convicção de Norton de Matos no seu colonialismo nacionalista e moderno (articulando vários matizes diferentes: socialismo utópico, eurocentrismo antropológico, demoliberalismo político, humanismo maçónico e capitalismo de cariz keyneseano, ou seja, estimulado pelo investimento público forte), mas também o seu lúcido receio de que o pós-Guerra e a tensão crescente gerada pela Guerra Fria ameaçavam a presença portuguesa no Ultramar e das duas uma: ou se construía a sua Utopia colonial ou se esfumaria a derradeira e melhor "ideia de Império"!...

Sabemos pelo autor que interrompeu a redaç̧ão do V volume a partir de inícios desse ano, informando-nos ainda que entregou como pronto o volume IV em Maio de 1945. Estaria assim a trabalhar ao mesmo tempo, tendo suspendido a escrita de um, para terminar o outro. Não reatou, porém, o labor já encetado. Porquê? Poderia pensar-se que alguma pressão ou mesmo imposição de natureza política tivesse levado a essa suspensão. Mas, por um lado, estava-se ainda na aparente primavera de esperança que acompanhara a vitória dos Aliados e, por outro, a intervenção na Grande Guerra, tema do volume $V$, havia muito que tinha sido assumida por todas as correntes politicas como página gloriosa da História de Portugal e do seu Exército (o processo da evocação patriótica começara logo durante o sidonismo). É o próprio autor que, no texto do último volume, nos dá uma pista: circunstâncias diversas, e que não vêm para o caso, obrigaram-me a suspender tão largo projecto. Continha-se nesta frase, de tom reservado, um desabafo relacionado com factos da sua mais recolhida intimidade. Na verdade, nesse ano de 1945 agudizou-se um conflito que se arrastava com o genro, obrigando o general a afastar-se não só da sua filha doente como da própria casa que sonhara e construira. Essas circunstâncias encheram-no de desgosto e perturbaram profundamente a sua vida. Não deixou, porém, de desenvolver uma importante actividade política, mas não lhe foi possivel desfrutar da tranquilidade necessária à continuação do trabalho que se tinha proposto. E só passado o auge desta nova e intensa fase existencial, - a campanha para a presidência da república e o respectivo rescaldo psicológico -, voltou Norton de Matos às Memórias e Trabalhos da sua vida. Mas cabe agora perguntar também porquê e como recomeçou. Por um lado, voltava a estar do ponto de vista político numa posição intocável e de destaque. A idade, a acentuada demarcação relativamente aos comunistas e a legitimidade que as primeiras brisas dos ventos da história davam aos pontos de vista que defendia, reforçavam a autoridade da sua voz. Por outro lado, é de supor que amigos e editor tenham juntado as suas vozes para o convencer a deitar novamente mãos à obra. Aliás, a continuação estava por ele mesmo anunciada e fazia falta para rematar o edifício que decidira construir (SILVA, Armando Malheiro; NORTON, José Pedreira Castro - O General Norton de Mato e o seu tempo, 1867-1955. In: MATOS, Norton de-Memórias e trabalhos.., ob. cit., vol. 1, pp. 38-39).

35 MATOS, Norton de - A Nação una, ob. cit., p. 7. 
Mais adiante na mesma obra deparamos - e destacamos, aqui, a titulo meramente ilustrativo - o seu Desígnio ou Utopia do Portugal Maior:

\section{V- A Autonomia Administrativa de cada uma das partes da Nação (...)}

VI - A Civilização dos habitantes que os portugueses encontraram nas terras que descobriram e ocuparam e que há cinco séculos estão diligenciando transformar em portugueses como eles. (...)

VII - O Povoamento, com portugueses de cor branca, das terras ocupadas, tendo sempre em vista a constituição da nação Una como um povo único, oriundo de diversos povos e raças, que continuará perenemente a ser o povo português, cuja cor como que desapareça em presença da civilização igual, da língua única, dos mesmos usos e costumes, de mentalidade nacional idêntica - o Portugal Maior dos nossos sonhos seculares. $\mathrm{O}$ povoamento tem de ser feito por famílias, por grupos de famílias, principalmente. Nunca esquecer no seu planear a mulher portuguesa.

VIII - Vem a seguir o levantar, sobre estes três pilares, do edifício grandioso que será Portugal de Aquém e de Além-Mar. Esta grande acção nacional conseguirse-á principalmente pelo desenvolvimento em larga escala das regióes portuguesas do Ultramar ${ }^{36}$

Lendo com atenção o seu último livro, publicado em vida, percebe-se tratar-se de um manifesto de reafirmação do seu visionarismo político-colonial e do prolongamento das Memórias e trabalhos..., como é evidenciado pelos títulos de vários capítulos no quadro abaixo:

\begin{tabular}{|c|c|}
\hline $\begin{array}{l}\text { [parte ] } \\
\text { Evocação }\end{array}$ & $\begin{array}{l}\text { A minha acção em angola: governador geral, } \\
\text { de } 17 \text { de junho de } 1912 \text { a } 6 \text { de março de } 1915 \text {. Alto comissário da república, } \\
\text { de } 16 \text { de abril de } 1921 \text { a } 30 \text { de junho de } 1924 \text { (p. 21-202) }\end{array}$ \\
\hline Cap. 1 & A Posse (pp. 23-25) \\
\hline Cap. 2 & A Conspiração (pp. 26-28) \\
\hline Cap. 3 & $\begin{array}{l}\text { A Primeira Transformação de Angola. Passagem da organização administrativa militar para a organização } \\
\text { administrativa civil (pp. 29-36) }\end{array}$ \\
\hline Cap. 4 & A Segunda Transformação de Angola. As Estradas (pp. 37-42) \\
\hline Cap. 5 & $\begin{array}{l}\text { A Terceira Transformação de Angola Proibição do comércio de pólvora e armas e o desenvolvimento } \\
\text { da Província (pp. 43-45) }\end{array}$ \\
\hline Cap. 6 & $\begin{array}{l}\text { A Quarta Transformação de Angola. Assistência média aos indígenas e melhoria das suas condições } \\
\text { de vida (pp. 46-55) }\end{array}$ \\
\hline Cap. 7 & O Congresso de Medicina Tropical [16 a 23 de Julho de 1923] (pp. 56-60) \\
\hline Cap. 8 & A Quinta Transformação de Angola. Proibição de bebidas alcoólicas (pp. 61-64) \\
\hline Cap. 9 & $\begin{array}{l}\text { A Sexta Transformação de Angola. O novo indígena: - da condição de trabalhador recrutado para o } \\
\text { de proprietário e cultivador rural. O aumento de produção. Os géneros pobres (pp. 65-89) }\end{array}$ \\
\hline Cap. 10 & A Sétima Transformação de Angola. A Educação e a Instrução (pp. 90-108) \\
\hline Cap. 11 & $\begin{array}{l}\text { A Oitava Transformação de Angola. A vida de família e conforto dos europeus. Habitaçóes, transportes, } \\
\text { comunicaçóes, segurança e ordem pública (pp. 109-117) }\end{array}$ \\
\hline
\end{tabular}

${ }^{36}$ MATOS, Norton de - A Nação una, ob. cit., pp. 8-9. 


\begin{tabular}{|l|l|}
\hline $\begin{array}{c}\text { [parte ] } \\
\text { Evocação }\end{array}$ & $\begin{array}{c}\text { A minha acção em angola: governador geral, } \\
\text { de } 17 \text { de junho de 1912 a 6 de março de 1915. Alto comissário da república, } \\
\text { de 16 de abril de 1921 a 30 de junho de 1924 (p. 21-202) }\end{array}$ \\
\hline Cap. 12 & $\begin{array}{l}\text { A Organização Financeira. O pouco que pude fazer como Governador Geral; o que fiz como Alto- } \\
\text { Comissário da República (pp. 118-144) }\end{array}$ \\
\hline Cap. 13 & Organização e Montagem das Instituiçôes Administrativas (pp. 145-174) \\
\hline Cap. 14 & Concessões de terrenos e Outras (pp. 175-181) \\
\hline Cap. 15 & $\begin{array}{l}\text { A Questão Racial (pp. 182-202) } \\
\text { NB: os Capítulos 16 [Explanação do Desígnio A) A Unidade Nacional Números 1 a 7] e 17 [Continuação } \\
\text { B) Organização e Administração [Números 8 a 36] concentram o plano estratégico de princípios e } \\
\text { medidas concretas para que Portugal Maior se cumpra }\end{array}$ \\
\hline
\end{tabular}

No mesmo ano de 1953, mas em Janeiro, saía dos prelos África Nossa, servido por um subtítulo longo com a força de todo um programa: o que queremos e o que não queremos nas nossas terras de África. Na folha de rosto, o autor achou por bem incluir uma epígrafe da sua lavra que sintetiza na perfeição a sua aposta perene num memorialismo de defesa e combate:

Tudo o que fizeste e julgaste bom, o que o teu trabalho criou, o que a tua experiência aperfeiçoou, tudo o que dos teus actos crês ter resultado de bem, de confiança, de esperança e de alegria para os homens, tudo o que te consola e te orgulha por a ti se dever, - conta-o, proclama-o e repete-o continuadamente, como de cima de uma alta coluna onde estivesses colocado: - e que no solo onde ela se levanta, fiquem os teus erros, as tuas fraquezas e os teus desânimos.

Este livro de 199 páginas formou-se em torno de dez artigos publicados, havia pouco tempo, por Norton de Matos em O Primeiro de Janeiro, como explicou nas primeiras linhas do Prefácio e cujas linhas finais rezam assim:

Os dez artigos que vão ler-se neste opúsculo; alguns que os antecederam e que indicam a evolução no meu pensamento; as palavras deste Prefácio e as que se lhe seguem; a exposição da Unidade Nacional; a minha Circular de 17 de Abril de 1913; e a legislação que, mais ou menos directamente, se prende com a protecção, à dignificação e à assimilação dos bantas, mostrarão o que mais conveniente julgo para se realizar a obra civilizadora em que há tantos séculos estamos empenhados.

Apresento apenas as traves mestras do edifício a erguer; os alicerces fui busca-los à nossa história, ao génio do povo português e procurei humildemente seguir o exemplo que nos deixaram os nossos maiores em terras da África e da Índia; os pormenores, se alguns tracei, foi apenas para me fazer compreender melhor, para indicar a linha geral do caminho a seguir e para pedir que o percorram depressa ${ }^{37}$

${ }^{37}$ MATOS, Norton de - África nossa, ob. cit., p. 28. A estrutura deste livro é a seguinte: 1 - Prefácio (pp. 9-28); II - Exortação aos habitantes do Ultramar Português (p. 31-51); III - Os dez artigos de "O Primeiro de Janeiro" [em que repudia, em prol do assimilacionismo, a tese "a África para os Africanos" e evoca o seu passado de Governador Geral e de Alto-Comissário em Angola] (p. 55-113); IV - Referencia e considerações sobre artigos antecedentes [inclui quatro artigos seus, três dos quais publicados em "O Primeiro de Janeiro": (1) Como pretendi povoar Angola, de Outubro de 1933; (2) Ocupação intensiva do território nacional, de 28 de Junho de 1948; (3) A Civilização Africana, de 16 de Outubro de 1951; (4) Uma 
Estendendo a leitura de $A$ Nação Una e de África Nossa ao tomo 6 da reedição em três volumes das Memórias e trabalhos... não repugna admitir que estas unidades textuais aparecessem interligadas num único volume, "limpo" de algumas repetições. Bastam, para confirmar esta ideia, as palavras iniciais do Esclarecimento (de abertura do tomo VI, vol. III): Não me foi possivvel, apesar das suas 368 páginas, incluir inteiramente no tomo III das minhas "Memórias" as linhas principais do meu plano de transformação de Angola, que tentei levar a cabo em dois governos desta grande província de Portugal ${ }^{38}$. Mas podemos ir um pouco mais longe e reproduzir aqui a titulação dos capítulos das primeira e segunda partes da obra:

\begin{tabular}{|c|c|}
\hline $\begin{array}{l}\text { I } \\
\text { o passado } \\
\text { esente }\end{array}$ & $\begin{array}{l}\text { Cap. } 1 \text { Uma conferência realizada na Bélgica } \\
\text { Cap } 2 \text { discurso pronunciado na sessáo solene do congresso de medicina tropical, primeiro } \\
\text { que se realizou em áfrica } \\
\text { Cap. } 3 \text { "Regimento" dado pelo rei d. Manuel I sobre os passos a dar para colonizar o } \\
\text { Congo } \\
\text { Cap. } 4 \text { Finalidade histórica (discurso de } 23 \text { de novembro de 1923) // discurso na cămara } \\
\text { municipal de Lisboa } \\
\text { Cap. } 5 \text { Um artigo }\end{array}$ \\
\hline $\begin{array}{l}\text { Parte II } \\
\text { Os regimes aduaneiros } \\
\text { do ultramar português } \\
\text { no quadro da unidade } \\
\text { nacional }\end{array}$ & $\begin{array}{l}\text { Cap. } 1 \text { Regime alfandegário dentro da nação una } \\
\text { Cap. } 2 \text { Preferências } \\
\text { Cap. } 3 \text { A minha reforma aduaneira de Angola } \\
\text { Cap. } 4 \text { Decreto } \mathrm{n}^{\circ} 169 \text {, de } 23 \text { de junho de } 1922 \text {, do alto-comissário da república em } \\
\quad \text { Angola } \\
\text { Cap. } 5 \text { Portaria provincial do governador geral de Angola, norton de matos, de } 12 \text { de } \\
\quad \text { março de } 1913 \\
\text { Cap. } 6 \text { Comentários finais } \\
\text { Cap. } 7 \text { A minha concepção de nação portuguesa (artigo publicado no boletim da sociedade } \\
\quad \text { luso-africana do Rio de Janeiro, em setembro de 1933) }\end{array}$ \\
\hline
\end{tabular}

E se continuarmos a ler da frente para trás, as ressonâncias e semelhanças prosseguem nos dois tomos reunidos no segundo volume das Memórias e trabalhos... No tomo 3 há duas partes. A primeira intitulada A Situação de Angola em 1912-1913, com dois capítulos (Cap. 1 - Análise Geral, p. 7-64, e Cap. 2 - Os Obstáculos Permanentes, p.65-113 ). A segunda intitulada As Sete Grandes Transformações de Angola em oito capítulos salpicados de gravuras e que corresponde bastante à parte Evocação do livro A Nação Una. Pode dizer-se, sem exagero, que a segunda parte do tomo 3 das Memórias e trabalhos... reaparece, com modificações e supressões, no último grande sopro discursivo do general.

No tomo 4 do vol. 2 é possível detectar a intenção do autor de evocar o importante papel desempenhado na preparação do C.E.P. e da intervenção de Portugal na Guerra de 1918-1918. Ela está patente no Cap. 2 A preparação da invasão de Angola

Experiência de colonização em Angola] (p. 117-143); V - A Unidade Nacional (p. 147-150); VI - Circular do Governador Geral de Angola, de 17 de Abril de 1913 (p. 153-174); VII - Cópia de alguns artigos do regulamento das Circunscriçôes Civis, de 17 de Abril de 1913, a que se refere a circular da mesma data, que acaba de ler-se (p. 175-184); e VIII - Medidas, deliberações e legislação sobre os naturais dos territórios portugueses d'Além-Mar (pp. 187-199).

${ }^{38}$ MATOS, Norton de - Memórias e trabalhos..., ob. cit., vol. 3, tomo 6, p. 471. 
e Moçambique pela Alemanha (p. 339-443), onde se sucedem elementos dispostos de forma a reforçar a tese, cara a Norton de Matos, de que a Alemanha pretendeu expulsar Portugal de Angola e de Moçambique, tese que formou e pôde constatar no terreno enquanto Governador Geral e que o motivou na sua postura guerrista e intervencionista: Portugal não poderia deixar de ir para a Flandres a fim de derrotar os Impérios Centrais e defender as suas possessóes ultramarinas. O seu anglofilismo genealógico e intelectual impediam-no de ver a Grã-Bretanha como uma infiel e pouco fiável Aliada. Uma espécie de germanofobia obcecou-o plenamente, impedindo-o de desconfiar da atitude dúbia e comprometida dos ingleses face ao expansionismo imperial germânico. No seu estilo algo avulso e dispersivo Norton de Matos não se esqueceu dos argumentos denunciadores das pretensões africanas dos alemães na parte primeira intitulada Angola no Mapa de África (p. 251-261) e na parte terceira África Politica (p. 305-400) do tomo 2 do vol. 1 das Memórias e trabalhos...

A evocação da obra político-administrativa iniciada, retomada e interrompida em Angola, bem como as premissas e valores do Portugal Maior ou da Nação Una pressupõem uma crítica que se percebe patente no livro de 1953 e no tomo 6, dedicado à sobrinha D. Emília da Silva Dias Norton de Matos, em Ponte de Lima, a 25 de Outubro de 1951, ao modelo colonial que o Estado Novo adoptou e implementou através da acção ministerial de Armindo Monteiro ${ }^{39}$, modelo patente no essencial das críticas dirigidas por Cunha Leal e outros à política do Alto-Comissário em Angola de 1921 a 1924 e que não rompia com a estreita visão de controlo apertado da administração e finanças dos governos coloniais e de aproveitamento dos recursos das colónias, explorando a mão-de-obra e investindo pouco em infra-estruturas de acordo com uma lógica absentista e avara de risco financeiro mínimo em territórios que se possuíam e se exibiam como legado imperial, mas em que não se deveria mexer muito...

A auto-defesa de Norton de Matos em matéria colonial e, especificamente, sobre Angola dirigiu-se sempre para os que dentro da "sua" República o criticaram e contra os que partilharam as mesmas ideias desses críticos já sob a batuta de Oliveira Salazar. Por isso, não deixou de ser surpreendente e uma efectiva reviravolta, justificada pelo eclodir da guerra colonial, quando, em 13 de Abril de 1961, foi empossado Ministro do Ultramar o Doutor Adriano José Alves Moreira (permaneceu em funções apenas até 4 de Dezembro de 1962), cujo pensamento e acção se revelariam próximos e até na linha da Utopia nortoniana. Só que o anacronismo em política só pode redundar em fracasso... Um modelo concebido e praticado na primeira metade do séc. XX (e já com reconhecido atraso) poderia ser viável na segunda metade desse mesmo século quando as principais potências colonizadoras haviam enveredado por processos em dominó de descolonização?!... Conhecemos a resposta... Nesse ano e alguns meses de governação ultramarina, se o general Norton de Matos ainda estivesse vivo (falecera seis anos antes) não deixaria de se sentir recompensado por ver as suas ideias de novo em prática. Uma sensação, porém, efémera, pois não tardaria muito a saborear, de novo, a amargura da derrota.

${ }^{39}$ Ver OLIVEIRA, Pedro Aires - Armindo Monteiro: uma biografia politica. Venda Nova: Bertrand Editora, 2000, pp. 75-126. 


\section{Tópico B}

Não deve surpreender que nos tenhamos estendido bastante no tópico anterior dada a centralidade que ele teve na estratégia memorialística de auto-defesa de Norton de Matos. Os outros tópicos recenseados tiveram uma expressividade menor e daí que possam ser abordados de forma mais sucinta.

A preocupação com a salvaguarda e o fomento das províncias ultramarinas, de acordo com a legislação e o modelo autonomista de final da Monarquia que a República haveria de consagrar e desenvolver, influenciou decisivamente o desempenho políticomilitar assumido por Norton de Matos como Ministro da Guerra nos Governos de Afonso Costa e da "União Sagrada", resultante da efémera aliança do Partido Democrático afonsista e do Partido Evolucionista de António José de Almeida ${ }^{40}$. Não se pode dizer que todos os guerristas se moveram pelo mesmo leit-motiv básico e não custa compreender que para um Afonso Costa ou um João Chagas o rompimento da "neutralidade beligerante", mantida pelos Governos até à insurreição militar de 14 de Maio de 1915 que derrubou o Executivo conservador do general Pimenta de Castro, fosse justificado pelo imperativo de criar um objectivo galvanizador e heróico capaz de superar as divisões internas no campo republicano, prestigiar a República no cenário internacional e junto das potências Aliadas, nomeadamente a Inglaterra, e neutralizar o "perigo espanhol". Estes objectivos não passaram indiferentes a Norton de Matos, mas na sua cabeça os apetites coloniais alemães constituíam a razão primeira para que Portugal ajudasse nas planícies da Flandres a cortar as cabeças da "hidra boche"...

Deixou descritos, logo nos tomos 1 e 2 das suas Memórias e trabalhos...., os contornos históricos dessa ameaça, mas foi no tomo 5 que concentrou a Segunda Parte (a primeira ficara no tomo 4) intitulada $A$ Caminho da Formação do Corpo do Exército Português. Do início da Primeira Guerra Mundial (3 de Agosto de 1914) à Parada de Montalvo em Tancos (22 de Julho de 1916). Escreveu-o não só para se defender dos anti-guerristas e de alguns germanófilos, sendo certo que a opção por um neutralidade condicionada pelo espírito do tratado da velha aliança com a Grã-Bretanha grassou entre o oficialato e as hostes republicanas, mas também e sobretudo para homenagear e exaltar o esforço da Raça, manifestado na intervenção militar de Portugal nos diferentes teatros de operaçôes da Grande Guerra ${ }^{41}$. Não foi, aliás, por acaso que o texto de abertura se intitula Apresentação em Palavras Antigas e solicitado para um relatório final da "Comissão dos Padrões da Grande Guerra", organismo composto por oficiais do exército, da armada e individuos da classe civil, antigos combatentes portugueses da Grande Guerra, empenhados em erigir de norte a sul do pais padrôes ou monumentos à memória dos soldados mortos nos campos de aço e sangue da Flandres.

A "Comissão dos Padrões da Grande Guerra" não mereceu ainda a atenção devida, mas ela teve influência no processo de decadência da I República e no comportamento político dos militares nos anos 20. No que respeita a Norton de Matos, o papel de destaque que exerceu desde a primeira hora ${ }^{42}$ e os laços de solidariedade que reforçou

\footnotetext{
${ }^{40}$ Ver TORGAL, Luís Reis - António José de Almeida e a República: discurso de uma vida ou vida de um discurso.. Seleç̧ão de imagens de Alexandre Ramires. Lisboa: Círculo de Leitores, 2004, pp. 141-151.

${ }^{41}$ MATOS, Norton de - Memórias e trabalhos..., ob. cit., vol. 3, tomo 5, p. 15.

42 Sobre este organismo ver Apêndice 1 de MATOS, Norton de - Memórias e trabalhos..., ob. cit., vol. 3, tomo 5, pp. 257-258.
} 
com camaradas de armas, de terra e mar, contribuiu, seriamente, para montar o "escudo protector" que o envolveu e protegeu do Estado Novo e seus algozes, recebendo de militares ligados à Ditadura Nacional e ao regime subsequente uma estima e um respeito que se entende no âmbito daquilo a que Raoul Girardet designou por société militaire ${ }^{43}$. Este aspecto explica, em parte, o seu posicionamento face ao "reviralhismo" ou à estratégia oposicionista de derrubar Salazar pela acção armada ${ }^{44}$. Distanciou-se desta via, alegando que se opunha ao enfrentamento fratricida entre militares: os camaradas de armas tinham o dever de solidariedade e cumplicidade entre si.

No Cap. 1 (p. 19-80) demarca-se da ambiguidade perante a Grande Guerra reflectida pelos Governos em contraponto à "atitude nacional" expressa nas ruas de várias cidades, onde a multidão congregava-se e ouviam-se as primeiras vivas à França, à Inglaterra e à Bélgica. Sentia-se que a Alemanha era o inimigo e que era mister ataca$l 0^{45}$. Nesse período, porém, ainda não seria visível a contestação à Guerra, transversal a diferentes sectores e grupos sociais de uma ponta a outra do pais e que era publicamente notória e reconhecida em finais de 1917. Ou, pelo menos, não o era, nem nunca foi para o obreiro do "Milagre de Tancos". No Cap. 2 não são poupadas críticas duras ao Governo, apelidado também de "ditadura”, do general Pimenta de Castro:

Quanto ao seu espírito e à sua maneira de actuar foi esta ditadura caracterizada pelo desprezo, o rancor e o ódio, a tudo o que representasse liberdade, democracia e respeito pela dignidade humana e, acima de tudo, pelo mais abjecto de quanto representasse manifestação verdadeira da opinião pública, quer encarnada em instituições parlamentares e livremente eleitas, quer exposta pela imprensa e pela palavra em reuniões públicas ou em assembleias de homens livres, quer emanada dos corpos municipais, quer manifestada na defesa e na acusação dos tribunais judiciais, quer erguida em clamor de protesto contra injustiças, violências, torturas e assassinatos policiais ${ }^{46}$

Elegantes e compreensivas são as referências ao Presidente da República desse conturbado período, o prestigiado e histórico republicano Manuel de Arriaga, que entregara o Poder ao seu velho amigo Pimenta de Castro. Sidónio Pais, futuro protagonista cimeiro da Segunda Ditadura (1917-1918), já nessa altura Ministro plenipotenciário de Portugal em Berlim, é denunciado como incapaz de perceber as intençôes expansionistas da Alemanha em Angola concretizadas no incidente de Naulila. Denúncia firmada nos documentos oficiais do Livro Branco, que constituem a principal fonte da narrativa tecida a partir do Cap. 2 até final do tomo e se acham alinhados muitos deles na Segunda Parte reservada a Apêndices (p. 257-466).

A sua participação na Junta revolucionária que depôs Pimenta de Castro é evocada, com contenção, no Cap. 2 (A Primeira Ditadura e o 14 de Maio de 1915), mas onde se espraia e se sente à vontade é a explicar as circunstâncias, os princípios e as medidas que assumiu para formar um Exército digno da Pátria ao lado das potencias amigas.

43 GIRARDET, Raoul - La Société militaire. Paris: Plon, 1953.

${ }^{44}$ Ver FARINHA, Luís - O Reviralho: revoltas republicanas contra a Ditadura e o Estado Novo, 1926 -1940. Lisboa: Editorial Estampa, 1998.

${ }^{45}$ MATOS, Norton de - Memórias e trabalhos..., ob. cit., vol. 3, tomo 5, p. 21

${ }^{46}$ MATOS, Norton de - Memórias e trabalhos..., vol. 3, tomo 5, p. 99. 
Este propósito apologético derrama-se pelos Caps. 4 (A Formação de um Exército) e 5 (A Concentração de Tancos) sem revelações novas ou surpreendentes. Em sua defesa transcreve aí trechos de autorizadas penas que justificam porque a revista e parada em Montalvo, em 22 de Julho de 1916, foram consideradas o coroar do Milagre de Tancos e porque não vingaram os boatos e as intrigas dos defectistas reunidos, pelo general, sob o epíteto depreciativo de 5. a coluna. Dando voz ao general Ferreira Martins, que era um dos mais ilustres escritores militares dos nossos tempos ${ }^{47}$, mostra como lhe pareceu adequada a expressão que se espalhou num ápice qual rastilho:

... enorme e prestantíssimo trabalho de organização e de instrução militar, cujo efeito surpreendente foi bem traduzido no nome por que ficou sendo conhecido no exército, - Milagre de Tancos! Milagre pode realmente chamar-se esse esforço hercúleo que conseguiu fazer sair em pouco tempo do nada, que era então o misérrimo exército português, uma divisão devidamente organizada e apetrechada que, durante cerca de três meses de trabalho insano de instrução no campo e nos arredores de Tancos, se preparou convenientemente para entrar em campanha na metrópole ou fora dela, onde quer que a chamasse o sagrado dever de bem servir a Pátria.

Milagre, na verdade, foi esse enorme prodígio realizado pela energia inflexível do ministro da Guerra, secundado pela actividade do seu gabinete e pelos esforços dedicados dos oficiais escolhidos para o comando, que tudo venceram, dificuldades, atritos, deficiências, tudo enfim quanto se opunha à efectivação de uma ideia que tinha como objectivo preparar tropas para a guerra ${ }^{48}$

Não é difícil aceitar que se tratou de uma operação gigantesca feita em tempo excepcionalmente curto, mas a historiografia actual vem mostrando que as deficiências e limitações, a excessiva dependência dos transportes ingleses e a falta de missão de muitos oficiais que deveriam dar o bom exemplo obrigam a olhar para o C.E.P. e para a intervenção portuguesa na Grande Guerra sem entusiasmo e sem glorificações patrióticas $^{49}$. È possível, contudo, reconhecer, a esta longa distancia, que Norton de Matos foi sincero, coerente e fervoroso nas suas convicções guerristas...

\section{Tópicos C e D}

Tanto empenho e tanta expectativa no esforço épico que entendeu ser impelido a realizar por vontade do Destino e da Pátria idolatrada, foram interrompidos brutal e dolorosamente pelo golpe militar de 5a 8 de Dezembro de 1918, liderado pelo major lente de Coimbra e ex-ministro em Berlim, Sidónio Bernardino Cardoso da Silva Pais (1872-1918). A mágoa e humilhação que Norton de Matos sentiu, não lavrou directamente nas Memórias e trabalhos..., ficando no recato dos seus apontamentos diarísticos, como este:

47 Ibidem, p. 249.

${ }^{48}$ Cit. MARTINS, Ferreira - Portugal na Grande Guerra in: MATOS, Norton de - Memórias e trabalhos..., ob. cit., vol. 3, tomo 5, pp. 249-250.

49 Ver SILVA, Armando Malheiro da - Sidónio e sidonismo, ob. cit., vol. 2, pp. 51-60 e 245-255. 
Londres, 8 de Dezembro de 1918.

Faz hoje um ano que do Palacio de Belem segui para bordo do navio inglez Woodnut, depois de saber que a minha casa tinha sido saqueada e que me andavam a procurar por toda a cidade para me assassinarem. Quando escrevi a carta junta (Doc. no 29) que a Esther trouxe consigo para Hespanha, ainda não sabia do saque da minha casa. Como podia eu adivinhar tamanha infamia. O amigo que me deu guarida, a que me refiro na carta, foi o Bernardino Machado, que, depois de eu ter deixado de ser Ministro, me ofereceu para ficar escondido no Palacio de Belem. O João de Menezes, que esteve comigo no mesmo Palácio na madrugada de 8, tambem me ofereceu para ir para casa dele. Igual oferecimento me fez o Mousinho de Albuquerque pelas 14 horas de 8, fazendo-me ver os inconvenientes que havia em eu ficar onde estava. Por fim, como as noticias de Lisboa fossem cada vez peores, resolven que eu fosse para bordo do navio inglez que se encontrava no Tejo e que estava armado em navio de guerra com flamula, o que representaria, como representou, absoluta segurança para a minha pessoa ${ }^{50}$.

Também é verdade que já não teve nem forças, nem vontade de alargar a narrativa memorialística à experiência empolgante e árdua que, com coragem e elevação, aceitou viver como candidato à Presidência da República ao longo de 1948, evidenciando, nesta aceitação e nos traços vários da sua conduta até à desistência imposta de dentro das suas fileiras de apoio, as matrizes da sua personalidade. Mas não calou a sua voz, nem evitou partilhar a lucidez do analista sempre bem informado e assaz atento ao que de significativo e impactante acontecia pelo Mundo, escolhendo um derradeiro acto público promovido pelos candidatos democratas de Aveiro às eleições para a Assembleia Nacional. $\mathrm{Na}$ impossibilidade de estar presente a uma sessão de propaganda efectuada em 21 de Outubro de 1953, aceitou o desafio para proferir uma conferência após um almoço na cidade aveirense.

O texto seria prontamente publicado e nele Norton de Matos não escondeu os crescentes receios perante o evoluir da política mundial e a "ameaça comunista" para a qual despertou emotivamente na sequência das divergências surgidas com os comunistas na fase final da sua candidatura presidencial ${ }^{51}$. De forma clara e na parte final da sua locução lança a pergunta: E dito isto para que vim eu aqui? Atalha célere: Vou dizê-lo:

Em primeiro lugar para fazer dois apelos, e o meu primeiro apelo será para que se combata o comunismo. (...)

O "meu segundo apelo" é dirigido ao actual Governo da Nação e principalmente a Sua Excelência o Senhor Presidente da República e ao Senhor Presidente do Ministério.

Consiste esse apelo em apontar a absoluta necessidade de se entrar francamente e rapidamente num regime de liberdade que politicamente coloque Portugal ao nível das grandes nações como sejam a França, a Inglaterra e os Estados-Unidos da America ${ }^{52}$

50 Miscelanea vol. $1^{\circ} 16$ de Setembro de 1918 a 15 de Setembro de 1919. De pag. 57 a pag. 72 desta "Miscelanea" fasem-se referencias a factos sucedidos desde 5 de Desembro de 1917 a 7 de Junho de 1918", pp. 57-58 (S.I.F.N.M.).

${ }^{51}$ Ver NORTON, José - Norton de Matos, ob. cit., pp. 403-410.

52 MATOS, Norton de - Conferência, ob. cit., p. 14-15. Texto transcrito na íntegra por SILVA, Armando Malheiro da - Para a história da oposição ao Estado Novo, art. cit., pp. 379-389; e Idem - O Major e o General, in: ob. cit., pp. 518-531. 
Muito mais que apelos, o essencial da mensagem do general configurou um grave e lúcido aviso que o Governo não saberia ouvir e que se perdeu no pó do tempo, embora viesse a ser validado pela História - a destinatária solene das centenas e centenas de laudas de evocações e de considerações legitimadoras do seu agir, querer e pensar.

Com efeito, a conferência de Aveiro, classificada pelo seu biografo como excepcional e última intervenção em público ${ }^{53}$, revestiu-se de uma extraordinária importância pelo que contém explícito e, sobretudo, implícito - o Mundo estava a mudar muito e as incertezas adensavam-se. Que fazer? Meter a cabeça e a "alma da raça" no passado? Ou encarar o futuro com os valores da liberdade, da democracia, da razão solidária e iluminista que puseram a Humanidade numa rota de progresso nunca vista? Uma rota de progresso e de novos perigos e ameaças, que urgia enfrentar e vencer...

O general deixou enunciado em Aveiro, "terra de liberdade" desde o primeiro quartel de oitocentos, um combate sério a travar. Legava-o, porém, aos amigos e admiradores, regressando ao seu quartel-refúgio para a retirada final... Tranquila e naturalmente.

${ }^{53}$ NORTON, José - Norton de Matos, ob. cit., pp. 416. 